\title{
Micorrização e indução de quitinases e $\beta$-1,3-glucanases e resistência à fusariose em porta-enxerto de videira
}

\author{
Murilo Dalla Costa(1), Paulo Emílio Lovato(2) e Paula Beatriz Sete ${ }^{(2)}$
}

\begin{abstract}
(1)Empresa de Pesquisa Agropecuária e Extensão Rural de Santa Catarina, Estação Experimental de Lages, Caixa Postal 181, CEP 88502-970 Lages, SC. E-mail: murilodc@epagri.sc.gov.br ${ }^{(2)}$ Universidade Federal de Santa Catarina, Departamento de Engenharia Rural, Rodovia Admar Gonzaga, №1.346, Bairro Itacorubi, CEP 88034-001 Florianópolis, SC. E-mail: plovato@mbox1.ufsc.br, paulasete@gmail.com
\end{abstract}

Resumo - O objetivo deste trabalho foi avaliar os níveis de expressão de $\beta$-1,3-glucanases e quitinases nos porta-enxertos de videira SO4 e R110, respectivamente suscetível e resistente a Fusarium oxysporum f. sp. herbemontis, bem como avaliar o efeito do fungo micorrízico arbuscular Glomus intraradices no crescimento, na expressão dessas enzimas e na supressão do patógeno no porta-enxerto suscetível. Foram quantificadas as atividades enzimáticas de $\beta$-1,3-glucanases e quitinases nas raízes dos porta-enxertos. Mudas do portaenxerto $\mathrm{SO} 4$ receberam inóculos de G. intraradices e F. oxysporum, e foram avaliadas quanto ao crescimento, atividade das duas enzimas e sintomas de doença. As atividades das enzimas nas raízes do porta-enxerto resistente aumentaram entre 0 e 5 dias após a inoculação do patógeno. A atividade de quitinases nas raízes do porta-enxerto suscetível aumentou com a inoculação do fungo micorrízico e do patógeno. A atividade de $\beta$-1,3-glucanases foi maior somente com a presença do fungo micorrízico e do patógeno. Videiras com inoculação de $G$. intraradices apresentaram diminuição nos sintomas de infecção por Fusarium spp., o que indica que o fungo micorrízico promove a indução de quitinases e $\beta$-1,3-glucanases especificamente na supressão ou inibição do patógeno.

Termos para indexação: Fusarium oxysporum, Glomus, Vitis.

\section{Mycorrhizal inoculation and induction of chitinases and $\beta-1,3-$ glucanases and fusarium resistance in grapevine rootstock}

\begin{abstract}
The objective of this work was to evaluate the expression levels of $\beta$-1,3-glucanases and chitinases in SO4 and 110 grapevine rootstocks, respectively susceptible and resistant to Fusarium oxysporum f. sp. herbemontis, as well as to evaluate the effect of the arbuscular mycorrhizal fungus Glomus intraradices on plant growth, on enzyme expression and on pathogen suppression in the susceptible rootstock. The enzyme activities of $\beta-1,3$-glucanases and chitinases in the rootstocks roots were evaluated. Plant growth, enzyme activity, and disease symptoms were evaluated in $\mathrm{SO} 4$ plantlets inoculated with $G$. intraradices and $F$. oxysporum. Enzyme activities in the plant roots increased in the resistant rootstock, between 0 and 5 days after pathogen inoculation. In the susceptible rootstock, chitinase activity enhanced after the mycorrhizal fungus and the pathogen inoculations. $\beta$-1,3-glucanase activity increased only in the presence of both the mycorrhizal and the pathogenic fungi. G. intraradices-inoculated $\mathrm{SO} 4$ grapevine plantlets showed decreased symptoms of Fusarium infection, which indicates that the mycorrhizal fungus promotes chitinase and $\beta-1,3$-glucanase activities leading to pathogen suppression or inhibition.
\end{abstract}

Index terms: Fusarium oxysporum, Glomus, Vitis.

\section{Introdução}

O declínio e morte de videiras é um dos principais problemas fitossanitários da viticultura do Sul do Brasil. Entre os principais agentes causais está o fungo do solo Fusarium oxysporum f. sp. herbemontis (Garrido et al., 2004), causador da fusariose. Este fungo infecta as videiras pelo sistema radicular e causa murcha vascular por obstrução do xilema, o que impede o transporte de água à parte aérea (Grigoletti Junior, 1985). O controle mais preconizado é o uso dos porta-enxertos resistentes Paulsen 1103 (Vitis berlandieri x V. rupestris), R99 ( $V$. berlandieri $\mathrm{x} V$. rupestris), VR043-43 ( $V$. vinifera $\mathrm{x}$ V.rotundifolia) e VR039-19 (V. vinifera $\mathrm{x}$ V.rotundifolia) (Schuck et al., 2007). Isso restringe o uso de genótipos de características agronômicas desejáveis, como os do

Pesq. agropec. bras., Brasília, v.45, n.4, p.376-383, abr. 2010 
grupo $V$. berlandieri $\mathrm{x} V$. riparia $(\mathrm{SO} 4$, Kober $5 \mathrm{BB}$, Solferino), suscetíveis ao patógeno (Grigoletti Junior, 1985).

Além de melhorar a absorção de nutrientes, especialmente o fósforo, a inoculação de fungos micorrízicos arbusculares pode reduzir a severidade de ataque de fungos causadores de doenças radiculares (Pozo et al., 2002; Borges et al., 2007). Durante o processo de colonização micorrízica, há indução de respostas de defesa que incluem a produção de enzimas do metabolismo de fenilpropanóides e de espécies reativas ao oxigênio, mas de caráter fraco, sem coordenação, temporário e localizado, em comparação a interações entre plantas e patógenos (García-Garrido \& Ocampo, 2002). Compostos de defesa (AzcónAguilar et al., 2002) ou sinais moleculares, como ácido jasmônico (Pozo \& Azcón-Aguilar, 2007), produzidos previamente pela presença de fungos micorrízicos arbusculares, sensibilizam os tecidos radiculares e tornam mais rápidas as respostas à infecção posterior por patógenos, o que permite a supressão de patógenos de modo mais eficiente do que em plantas não micorrizadas (Azcón-Aguilar et al., 2002). Dessa forma, micorrizas podem induzir respostas de natureza bioquímica e estrutural, como: produção de compostos fenólicos (Zhu \& Yao, 2004); formação de barreiras físicas na parede celular com deposição de calose (Cordier et al., 1998); expressão de proteínas relacionadas à patogênese, como $\beta$-1,3-glucanases, quitinases, fenilalanina amônia-liase, proteases e chalcona sintase (Pozo et al., 1999, 2002). Quitinases e $\beta$-1,3-glucanases são enzimas associadas à defesa das plantas contra $F$. oxysporum, pois degradam os polissacarídeos quitina e $\beta$-1,3-glucana, respectivamente (Lebeda et al., 2001), que estão entre os principais componentes da parede celular do patógeno (Schoffelmeer et al., 1999). Quitinases e $\beta$-1,3-glucanases são acumuladas no apoplasto das células vegetais, localização que permite a defesa contra o ataque de patógenos e que gera sinais moleculares capazes de ativar, no interior da célula, mecanismos para impedir o avanço e desenvolvimento da doença (Lebeda et al., 2001). Estudos relatam que entre quatro e cinco dias após a inoculação, ocorre um acúmulo transiente dessas enzimas pelo efeito indutor do patógeno (Ramamoorthy et al., 2002).

O objetivo deste trabalho foi avaliar os níveis de expressão de $\beta$-1,3-glucanases e quitinases, no sistema radicular de porta-enxertos de videiras - suscetível e resistente - a $F$. oxysporum f. sp. herbemontis, além de avaliar o efeito da inoculação do fungo micorrízico Glomus intraradices na expressão dessas enzimas e no crescimento de videiras e o efeito das enzimas e da formação de micorrizas na supressão de $F$. oxysporum f. sp. herbemontis, em genótipo de porta-enxerto suscetível ao patógeno.

\section{Material e Métodos}

No primeiro experimento, as atividades das enzimas quitinases e $\beta$-1,3-glucanases das raízes foram monitoradas entre zero e cinco dias após a inoculação de Fusarium spp. Foram utilizados os porta-enxertos $\mathrm{R} 110$ (Vitis berlandieri $\mathrm{x} \quad$ V. rupestris) e $\mathrm{SO} 4$ ( $V$. berlandieri x $V$. riparia) que apresentam, respectivamente, resistência e suscetibilidade a $F$. oxysporum f. sp. herbemontis (Grigoletti Junior, 1985). As plantas foram micropropagadas e aclimatizadas em bandejas alveoladas de poliestireno expandido, que continham substrato particulado, esterilizado a $121^{\circ} \mathrm{C}$ por 40 min, à base de composto orgânico termofílico, Nitossolo Vermelho distroférrico e areia $(1: 2: 2, \mathrm{v} / \mathrm{v} / \mathrm{v})$ (Zemke et al., 2003). As mudas dos porta-enxertos permaneceram em câmara de crescimento com fotoperíodo de 16 horas de radiação fotossinteticamente ativa $\left(150 \mu \mathrm{mol} \mathrm{m} \mathrm{m}^{-2} \mathrm{~s}^{-1}\right)$. Após 30 dias, ao término da aclimatização, as mudas dos porta-enxertos foram transferidas para vasos que continham $400 \mathrm{~mL}$ do mesmo substrato. Isolado de $F$. oxysporum f. sp. herbemontis, fornecido pela Embrapa Uva e Vinho, Bento Gonçalves, RS, foi multiplicado em placas de Petri com meio de cultura BDA. Após seis dias de cultivo em câmara de crescimento à temperatura de $25 \pm 2^{\circ} \mathrm{C}$, com intensidade luminosa de $150 \mu \mathrm{mol} \mathrm{m} \mathrm{m}^{-2} \mathrm{e}$ fotoperíodo de 16 horas de luz por dia, foram realizadas a adição de $15 \mathrm{~mL}$ de água a cada placa e a raspagem superficial do micélio de Fusarium spp. A suspensão obtida, ajustada para a concentração de $1 \times 10^{7}$ conídios $\mathrm{mL}^{-1}$, forneceu o inóculo do patógeno.

As raízes de mudas micropropagadas e aclimatizadas dos porta-enxertos de videira R110 e SO4, livres de substrato e seccionadas a $5 \mathrm{~cm}$ do colo, foram imersas na suspensão de conídios do patógeno ou em água estéril, por uma hora. Em seguida, as mudas foram replantadas nos vasos de origem. Amostras radiculares foram coletadas $0,24,48,72,96$ e 120 horas após a 
inoculação do patógeno ou imersão das raízes em água estéril. Após lavagem e separação da parte aérea, os tecidos radiculares foram acondicionados em recipientes de plástico, imersos em nitrogênio líquido e armazenados a $-40^{\circ} \mathrm{C}$. Amostras de raízes foram transferidas para almofariz, trituradas após adição de 0,2 g de polivinilpolipirrolidona (PVPP) e nitrogênio líquido, e homogeneizadas com solução extratora de proteínas (1:6, massa/volume) preparada conforme Schaefer(1977). A suspensão resultante foi centrifugada a $10.000 \mathrm{~g}\left(0^{\circ} \mathrm{C}\right.$, por $\left.20 \mathrm{~min}\right)$, e alíquotas do sobrenadante foram retiradas para quantificação do teor de proteínas e ensaios enzimáticos. A concentração de proteínas totais foi estimada conforme Kruger (2002), tendo-se utilizado albumina de soro bovino como padrão. Os ensaios enzimáticos para determinação espectrofotométrica da atividade de quitinases (EC 3.2.1.14) e $\beta$-1,3-glucanases (EC 3.2.1.39) foram realizados de acordo com Wirth \& Wolf (1992). Alíquotas de $100 \mu \mathrm{L}$ dos extratos proteicos foram transferidas para $500 \mu \mathrm{L}$ de tampão acetato $50 \mu \mathrm{mol}$ $\mathrm{L}^{-1}, \mathrm{pH} 5$, que continha $200 \mu \mathrm{L}$ da solução do substrato enzimático carboximetilquitina-remazol violeta brilhante utilizando $2 \mathrm{mg} \mathrm{mL}^{-1}$ de CM-Chitin-RBV (Loewe Biochemica $\mathrm{GmbH}$, Sauerlach, Alemanha). Em seguida, as alíquotas foram incubadas a $38^{\circ} \mathrm{C}$ por 2 horas. A reação foi interrompida pela adição de $\mathrm{HCl} 2 \mathrm{~mol} \mathrm{~L}^{-1} \mathrm{e}$ resfriamento por $10 \mathrm{~min}$ a $-20^{\circ} \mathrm{C}$. Após a centrifugação $(10.000 \mathrm{~g}, 5 \mathrm{~min})$, a absorbância a $550 \mathrm{~nm}$ do sobrenadante foi medida em espectrofotômetro. Como controle, utilizou-se solução dos reagentes sem extrato radicular. Os valores de leitura em espectrofotômetro foram ajustados quanto aos teores de proteínas totais dos extratos radiculares de cada amostra, e os resultados de atividade de quitinases foram expressos em unidades de absorbância (UA) a $550 \mathrm{~nm}$ por miligrama de proteína por hora. A determinação da atividade de $\beta$-1,3-glucanases foi conduzida de forma análoga, tendo-se diferenciado por utilizar carboximetilcurdlan-remazol azul brilhante e $4 \mathrm{mg} \mathrm{mL}^{-1}$ de CM-Curdlan-RBB (Loewe Biochemica $\mathrm{GmbH}$, Sauerlach, Alemanha), como substrato enzimático e estimar a absorbância da coloração azul formada a $600 \mathrm{~nm}$. Os valores foram corrigidos quanto aos teores de proteínas totais, e os resultados de atividade $\beta$-1,3-glucanases foram expressos em UA $600 \mathrm{~nm}$ por miligrama de proteína por hora.
O delineamento experimental foi em blocos inteiramente casualizados, com sete repetições e uma planta por repetição. Para cada porta-enxerto, formouse um fatorial 2x6 (dois tratamentos de inoculação de Fusarium spp. e seis períodos de monitoramento das atividades enzimáticas). Os dados foram submetidos à análise de variância; quando houve efeito significativo dos tratamentos, as médias foram separadas pelo teste de Newman-Keuls, a 5\% de probabilidade.

No segundo experimento, para verificar o efeito da inoculação micorrízica na supressão de Fusarium spp., mudas micropropagadas do porta-enxerto de videira SO4 foram aclimatizadas em bandejas alveoladas, que continham substrato esterilizado a $121^{\circ} \mathrm{C}$ por 40 min à base do substrato comercial Plantmax (Eucatex Agro), Nitossolo Vermelho distroférrico, areia $(2: 1: 2, \mathrm{v} / \mathrm{v} / \mathrm{v})$, com as seguintes características químicas: $\mathrm{pH}$ água (1:2,5), 5; P, $54 \mathrm{mg} \mathrm{dm}^{-3} ; \mathrm{K}, 222 \mathrm{mg} \mathrm{dm}^{-3} ; \mathrm{Al}, 0,2 \mathrm{cmol}_{\mathrm{c}}$ $\mathrm{dm}^{-3} ; \mathrm{Ca}, 4,4 \mathrm{cmol}_{\mathrm{c}} \mathrm{dm}^{-3} ; \mathrm{Mg}, 2,8 \mathrm{cmol}_{\mathrm{c}} \mathrm{dm}^{-3}$; CTC

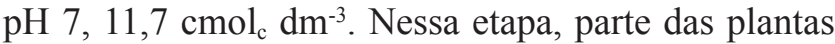
recebeu aproximadamente $2 \mathrm{~g}$ de inóculo do isolado de fungo micorrízico arbuscular Glomus intraradices N.C. Schenck \& G.S.Sm., constituído da mistura do substrato de crescimento e do sistema radicular do hospedeiro vegetal (Allium porrum), que formou o tratamento de videiras micorrizadas $(+\mathrm{Gi})$. O outro grupo de videiras formou o controle (-Gi), que teve a microbiota não-micorrízica reconstituída pela adição de $2 \mathrm{~mL}$ de suspensão filtrada ( $10 \mathrm{~g} \mathrm{~L}^{-1}$, filtro Whatman no 1) de inoculante do isolado de $G$. intraradices. As plantas permaneceram em crescimento, em câmara com fotoperíodo de 16 horas de radiação fotossinteticamente ativa $\left(150 \mu \mathrm{mol} \mathrm{m} \mathrm{m}^{-2} \mathrm{~s}^{-1}\right)$. Após 30 dias, ao término da aclimatização, as mudas do porta-enxerto foram transferidas para vasos com $400 \mathrm{~mL}$ do mesmo substrato e receberam novamente $2 \mathrm{~g}$ de inóculo de $G$. intraradices ou filtrado. As plantas permaneceram por 45 dias nessas condições, tendo recebido água a cada dois dias e, semanalmente, $2 \mathrm{~mL}$ de solução nutritiva de Long Ashton (Smith et al., 1983), com $10 \%$ da concentração original de fósforo. Ao final desse período, as plantas receberam inóculo de Fusarium spp., mediante poda das raízes, livres de solo, a $10 \mathrm{~cm}$ do colo da planta, e imersão em suspensão de conídios produzida conforme descrito anteriormente. Plantas controle tiveram as raízes imersas em água estéril. O delineamento foi completamente casualizado, com cinco repetições e 
uma planta por parcela experimental, em arranjo fatorial $2 \times 2$, composto por dois tratamentos de inoculação de $G$. intraradices (+Gi e -Gi) e dois de inoculação de $F$. oxysporum f. sp. herbemontis (+Fo e -Fo). As variáveis analisadas foram: massa de matéria fresca e seca da parte aérea e radicular; colonização micorrízica; atividade hidrolítica de quitinases e $\beta-1,3-$ glucanases; e índice de doença para sintomas internos e externos de F. oxysporum f. sp. herbemontis.

$\mathrm{O}$ crescimento da parte aérea e do sistema radicular das videiras foi avaliado por meio de pesagem das massas de matéria fresca e seca das videiras, no momento da amostragem e após secagem a $60^{\circ} \mathrm{C}$ por 72 horas, respectivamente. Os fragmentos de raízes provenientes da poda das plantas, no momento da imersão do sistema radicular em suspensão de conídios ou em água, foram submetidos à descoloração em $\mathrm{KOH}$ a $10 \%$ e $\mathrm{H}_{2} \mathrm{O}_{2}$ a $2 \%$, e coradas com $0,05 \%$ de azul de tripano em glicerol (Koske \& Gemma, 1989). A taxa de micorrização foi estimada de acordo com Trouvelot et al. (1986), após observação ao microscópio óptico. Amostras radiculares das mudas de videira, com aproximadamente $1 \mathrm{~g}$ de massa de matéria fresca, foram coletadas aos quatro dias após a inoculação do patógeno e foram submetidas à avaliação da atividade enzimática, de acordo com os procedimentos do experimento anterior.

Os critérios de avaliação de sintomas internos e externos da presença de infecção por Fusarium spp. foram aqueles adotados como índices de doença por Grigoletti Junior (1985). As notas e respectivos sintomas utilizados na avaliação do experimento foram as descritas

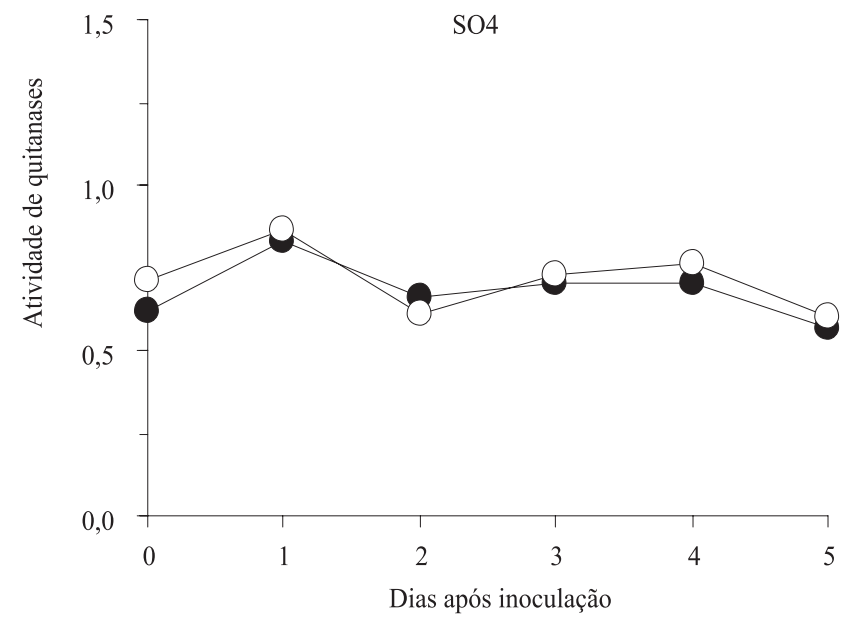

a seguir. Para sintomas externos utilizou-se: ausência de sintomas na planta; redução no crescimento da planta; amarelecimento das folhas basais; amarelecimento generalizado e necrose nos bordos das folhas e abscisão foliar; morte da planta. Para sintomas internos, os índices foram: ausência de sintomas nas raízes; descoloração vascular restrita às raízes com inóculo; descoloração vascular na base da estaca, próximo à inserção das raízes; descoloração vascular na parte mediana da estaca, logo acima da superfície do solo; descoloração vascular na parte apical da estaca. Os dados foram submetidos a análise de variância (teste F) e, em caso de essa ter sido significativa, foi aplicado o teste de separação de médias Newman-Keuls, a 5\% de probabilidade. O experimento foi repetido duas vezes.

\section{Resultados e Discussão}

Quando se considera todo o período de avaliação, a atividade de $\beta$-1,3-glucanases foi maior $(p<0,05)$ nas plantas com Fusarium spp. em comparação ao controle. Quanto à atividade de quitinases, os níveis foram superiores nas plantas com inóculo do patógeno porém não significativos $(\mathrm{p}=0,061)$. Nas raízes do porta-enxerto SO4, suscetível à Fusarium spp., a inoculação do patógeno não induziu alterações nos níveis de atividade de quitinases e $\beta$-1,3-glucanases (Figuras 1 e 2). O porta-enxerto R110, tolerante ao patógeno, apresentou aumento gradativo na atividade enzimática até o quarto dia após a inoculação.

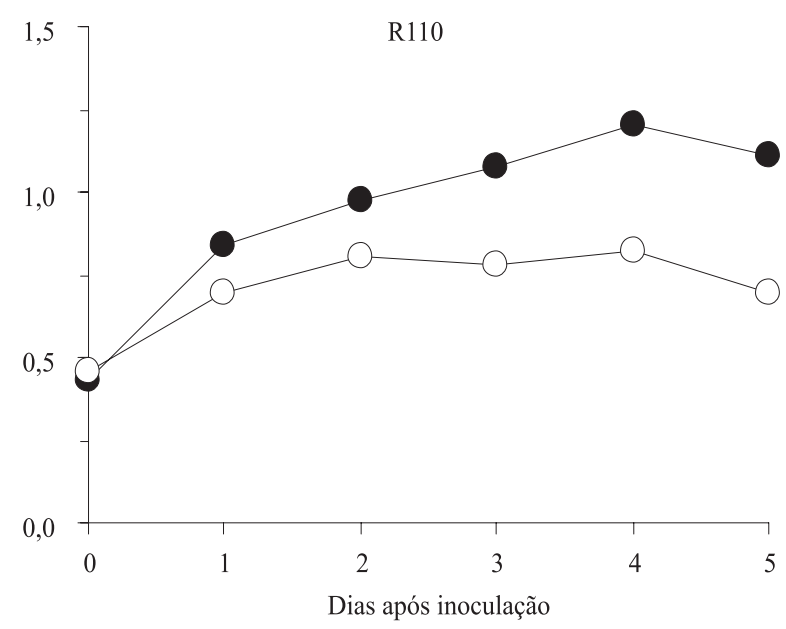

Figura 1. Atividade de quitinases (unidades de absorbância a $550 \mathrm{~nm}$ por miligrama de proteína por hora), em amostras radiculares de porta-enxertos de videira suscetível (SO4) e resistente (R110) a Fusarium oxysporum f. sp. herbemontis, coletadas entre um e cinco dias após a inoculação do patógeno (—•—) ou a imersão de raízes em água estéril (—o-). 
O aumento na concentração das proteínas relacionadas à patogênese, nas raízes do porta-enxerto de videira R110, indica que Fusarium spp. induziu respostas de resistência nas plantas. Assim, do momento da indução até o quarto dia após a inoculação do patógeno, ocorreu ativação de genes de defesa, síntese e acúmulo máximo das enzimas nos tecidos radiculares. Foi também constatado em raízes de tomateiros o acúmulo transiente de proteínas relacionadas à patogênese, entre três e cinco dias após a inoculação de F. oxysporum f. sp. lycopersici, o que indica ter havido reação de defesa da planta (Ramamoorthy et al., 2002).

O acúmulo conjunto de quitinases e $\beta$-1,3-glucanases é relacionado a um efeito sinérgico dessas enzimas que, em associação ou não a outras proteínas, ampliam as possibilidades de ação e a eficiência da planta na supressão de patógenos (Veronese et al., 2003). O fato de esse acúmulo ter sido constatado somente no porta-enxerto R110 indica que a síntese dessas enzimas

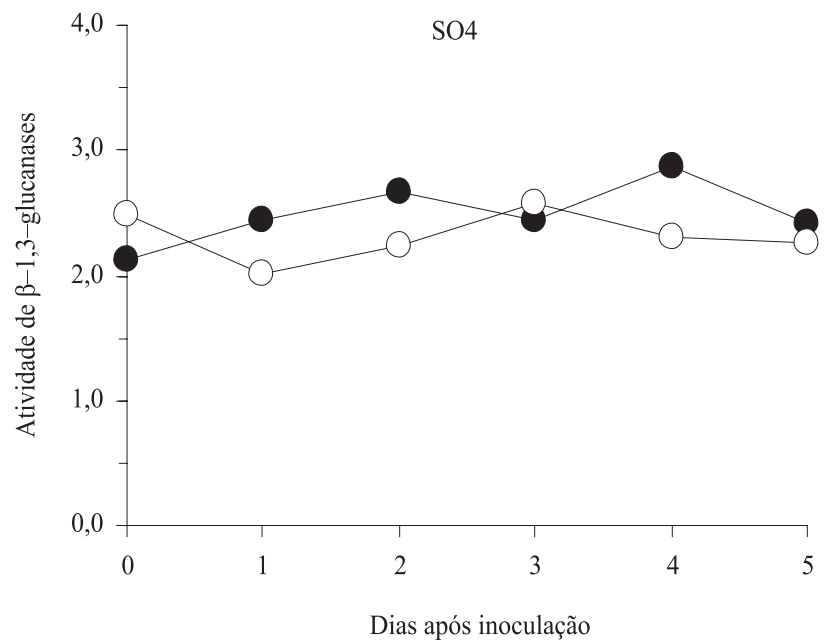

hidrolíticas pode constituir uma ação do genótipo de videira resistente, para suprimir o processo infectivo de Fusarium spp. Os níveis mais altos de atividade e a expressão diferenciada de isoformas de quitinases e $\beta$-1,3-glucanases, em variedades resistentes de plantas, foram constatados em vários patossistemas (Tuzun, 2001). Assim, pode-se concluir que a atividade de quitinases e $\beta$-1,3-glucanases, em raízes de videira $\mathrm{R} 110$, atingiu os níveis mais altos quatro dias após a inoculação de $F$. oxysporum f. sp. herbemontis. A síntese e o acúmulo transiente de quitinases e $\beta$-1,3-glucanases, em raízes de porta-enxerto resistente a $F$. oxysporum f. sp. herbemontis, pode ser meio de supressão do processo infectivo do patógeno.

No segundo experimento, o acúmulo de biomassa vegetal no momento da inoculação do patógeno, aos 45 dias após a inoculação, no final da aclimatização ex vitro (Tabela 1), comprova a eficiência da associação do porta-enxerto de videira com $G$. intraradices.

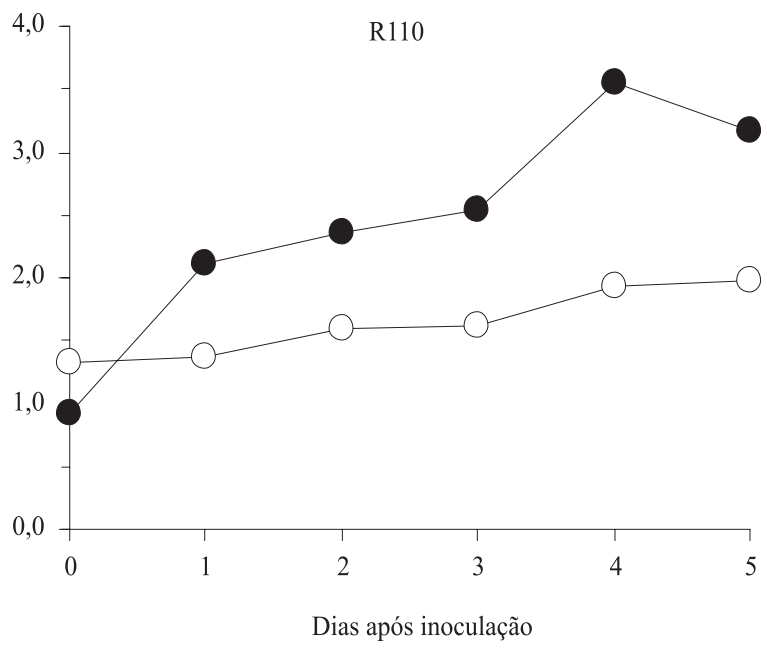

Figura 2. Atividade de $\beta$-1,3-glucanases (unidades de absorbância a UA $600 \mathrm{~nm}$ por miligrama de proteína por hora), em amostras radiculares de porta-enxertos de videira - suscetível (SO4) e resistente (R110) a Fusarium oxysporum f. sp. herbemontis coletadas entre um e cinco dias após a inoculação do patógeno (-•—) ou a imersão de raízes em água estéril (—०—).

Tabela 1. Massas de matéria fresca da parte aérea (MFPA, g) e do sistema radicular (MFSR, g), relação entre massas de matéria fresca do sistema radicular e parte aérea (SR/PA), taxa de colonização do córtex radicular $(\mathrm{M})$ e concentração de arbúsculos na fração radicular micorrizada (a), em mudas micropropagadas do porta-enxerto de videira SO4, após 45 dias da inoculação (+Gi) ou não (-Gi) de Glomus intraradices, na fase de aclimatização ex vitro ${ }^{(1)}$.

\begin{tabular}{|c|c|c|c|c|c|c|}
\hline Tratamento & MFPA & MFSR & Total & SR/PA & $\mathrm{M}(\%)$ & $\mathrm{a}(\%)$ \\
\hline$+\mathrm{Gi}$ & $2,40 \pm 0,05 \mathrm{a}$ & $2,48 \pm 0,05 \mathrm{a}$ & $4,88 \pm 0,07 \mathrm{a}$ & $1,04 \pm 0,03 b$ & $77 \pm 3$ & $40 \pm 3$ \\
\hline$\underline{-G i}$ & $1,07 \pm 0,05 \mathrm{~b}$ & $1,46 \pm 0,02 b$ & $2,53 \pm 0,06 \mathrm{~b}$ & $1,38 \pm 0,07 \mathrm{a}$ & 0 & 0 \\
\hline CV (\%) & 9 & 5 & 5 & 12 & - & - \\
\hline
\end{tabular}

${ }^{(1)}$ Médias \pm erro-padrão, seguidas de letras iguais, nas colunas, não diferem entre si pelo teste de Newman-Keuls a 5\% de probabilidade $(\mathrm{n}=5$ ). 
A presença de hifas e arbúsculos no córtex, em taxas elevadas, indica a formação de micorriza funcional, e em nível superior ao mínimo (acima de 50\%), tido como necessário para a ocorrência do efeito supressivo a patógenos por micorrizas (Cordier et al., 1998). A razão entre massa de matéria fresca do sistema radicular e da parte aérea (SR/PA) foi menor em plantas micorrizadas, o que significa menor custo para a manutenção das estruturas fúngicas, nas quais se incluem as hifas extrarradiculares responsáveis pela absorção de nutrientes, e permite a realocação de fotossintatos e maior crescimento da parte aérea.

A inoculação do fungo micorrízico e do patógeno nas videiras acarretou diferenças na concentração de proteínas em amostras radiculares. O nível foi $35 \%$ maior em plantas não micorrizadas, em comparação a plantas micorrizadas, e 44\% maior nas videiras com o patógeno, em comparação ao controle (Tabela 2). $O$ perfil de atividade hidrolítica dos tratamentos foi diferente entre as enzimas quitinases e $\beta-1,3$-glucanases. A produção de quitinases nas plantas micorrizadas e com Fusarium spp. pode constituir resposta à presença dos microssimbiontes com função diversa para cada situação. A inoculação de fungos micorrízicos arbusculares pode induzir isoformas específicas de quitinases e $\beta$-1,3-glucanases diferentes das presentes em níveis basais (Salzer et al., 2000; Pozo et al., 2002). Além disso, fungos micorrízicos podem aumentar a indução de isoformas acima de níveis basais, o patógeno radicular pode induzir a expressão de isoformas

Tabela 2. Teores de proteínas totais ( $\mathrm{mg} \mathrm{g}^{-1}$ de raiz fresca) e atividade enzimática de quitinases (unidade de absorbância a $550 \mathrm{~nm}$ por miligrama de proteína por hora) e $\beta$-1,3-glucanases (unidade de absorbância a $600 \mathrm{~nm}$ por miligrama de proteína por hora), em amostras radiculares de mudas micropropagadas do porta-enxerto de videira SO4, submetidas à inoculação com Glomus intraradices (Gi) e Fusarium oxysporum f. sp. herbemontis (Fo), quatro dias após a inoculação do patógeno ${ }^{(1)}$.

\begin{tabular}{lccc}
\hline Tratamento & Proteínas totais & \multicolumn{2}{c}{ Atividade enzimática } \\
\cline { 3 - 4 } & & Quitinases & $\beta$-1,3-glucanases \\
\hline +Gi +Fo & $1,6 \pm 0,3$ & $2,6 \pm 0,7 \mathrm{a}$ & $2,2 \pm 0,6 \mathrm{a}$ \\
-Gi +Fo & $2,0 \pm 0,2$ & $2,5 \pm 0,8 \mathrm{a}$ & $0,9 \pm 0,3 \mathrm{~b}$ \\
+Gi -Fo & $1,0 \pm 0,1$ & $3,0 \pm 0,8 \mathrm{a}$ & $1,1 \pm 0,2 \mathrm{~b}$ \\
-Gi -Fo & $1,5 \pm 0,1$ & $0,6 \pm 0,2 \mathrm{~b}$ & $1,1 \pm 0,4 \mathrm{~b}$ \\
\hline CV (\%) & 43 & 60 & 65 \\
\hline
\end{tabular}

${ }^{(1)}$ Médias \pm erro-padrão, seguidas de letras iguais, nas colunas, não diferem entre si pelo teste de Newman-Keuls, a $5 \%$ de probabilidade $(n=5)$. específicas, e plantas micorrizadas e com inóculo do patógeno podem expressar isoformas diversas das demais (Pozo et al., 2002; Garmendia et al., 2006). Mudas de pimentão, micorrizadas com $G$. deserticola, induziram a expressão de três isoformas ácidas de quitinases, que foram detectadas após dois meses da inoculação do fungo micorrízico (Garmendia et al., 2006), o que indica que o nível de atividade da enzima no tratamento $+\mathrm{Gi}-\mathrm{Fo}, 45$ dias após a segunda inoculação de $G$. intraradices, está relacionada ao processo de estabelecimento e funcionamento da micorriza. Nesse mesmo tratamento, a expressão de $\beta$-1,3-glucanases acima dos níveis basais não foi constatada. Em tomateiro, Pozo et al. (1999) detectaram duas isoformas de $\beta$-1,3-glucanases, induzidas somente pela colonização radicular por G. mosseae, fato não observado pela inoculação com $G$. intraradices.

Níveis elevados de atividade enzimática de $\beta$-1,3-glucanases foram constatados somente no tratamento $+\mathrm{Gi}+\mathrm{Fo}$, que apresentou diminuição nos sintomas internos de infecção por Fusarium spp. 90 dias após a inoculação do patógeno (Tabela 3). Em tomateiros com $G$. intraradices, o efeito supressivo a $F$. oxysporum f. sp. lycopersici foi relacionado à nutrição em fósforo, e o aumento no crescimento da planta à simbiose mutualística (Akköpru \& Demir, 2005). Além da relação com a melhora do status nutricional, a expressão de quitinases e $\beta$ - 1,3 -glucanases acima dos níveis basais pode ter contribuído para a diminuição da infecção por Fusarium spp. (Tabela 2). $\mathrm{O}$ aumento da atividade hidrolítica em plantas micorrizadas é indicação da expressão de genes, em resposta à presença do patógeno no sistema radicular, e constitui barreira química ao processo infectivo ou serve de sinal bioquímico para a expressão de eventos relacionados à defesa da planta. A atividade inibidora dessas enzimas hidrolíticas, no crescimento de espécies de Fusarium, foi constatada em ensaios in vitro e ocorre pela lise das extremidades das hifas (Nóbrega et al., 2005). Nesse sentido, a expressão de isoformas de $\beta$-1,3-glucanases, induzidas por micorrizas em tomateiro exposto a Phytophthora (Pozo et al., 1999), indica que a enzima está relacionada à proteção contra o fungo patogênico. Há relação entre os níveis de atividade hidrolítica de quitinases e $\beta$-1,3-glucanases, estimadas por meio de substratos específicos, e a expressão de isoformas, obtidas em géis de eletroforese (Cachinero et al., 2002; Deytieux et al., 2007). Assim, 
Tabela 3. Índice de doença de sintomas internos e externos, massa de matéria seca, taxa de colonização do córtex radicular (M) e concentração de arbúsculos, na fração radicular micorrizada (a) de mudas micropropagadas do porta-enxerto de videira SO4, submetidas à inoculação com Glomus intraradices (Gi) e Fusarium oxysporum f. sp. herbemontis (Fo), quatro dias após a inoculação do patógeno ${ }^{(1)}$.

\begin{tabular}{|c|c|c|c|c|c|}
\hline \multirow[t]{2}{*}{ Tratamento } & \multicolumn{2}{|c|}{ Índice de doença } & \multirow{2}{*}{$\begin{array}{c}\text { Massa de matéria } \\
\operatorname{seca}(\mathrm{g})\end{array}$} & \multirow[t]{2}{*}{ M (\%) } & \multirow[t]{2}{*}{ a (\%) } \\
\hline & Sintomas internos & Sintomas externos & & & \\
\hline$+\mathrm{Gi}+\mathrm{Fo}$ & $3,2 \pm 0,2 b$ & $2,9 \pm 0,4 b$ & $1,52 \pm 0,10 \mathrm{~b}$ & $77 \pm 2$ & $63 \pm 8$ \\
\hline$-\mathrm{Gi}+\mathrm{Fo}$ & $4,0 \pm 0,3 \mathrm{a}$ & $4,0 \pm 0,3 \mathrm{a}$ & $0,22 \pm 0,04 \mathrm{c}$ & $0 \pm 0$ & $0 \pm 0$ \\
\hline$+\mathrm{Gi}-\mathrm{Fo}$ & $1,0 \pm 0,0 \mathrm{c}$ & $1,0 \pm 0,0 \mathrm{c}$ & $2,41 \pm 0,21 \mathrm{a}$ & $66 \pm 5$ & $63 \pm 9$ \\
\hline -Gi -Fo & $1,0 \pm 0,0 \mathrm{c}$ & $1,0 \pm 0,0 \mathrm{c}$ & $0,45 \pm 0,06 \mathrm{c}$ & $0 \pm 0$ & $0 \pm 0$ \\
\hline $\mathrm{CV}(\%)$ & 26 & 33 & 34 & 28 & 55 \\
\hline
\end{tabular}

${ }^{(1)}$ Médias \pm erro-padrão, seguidas de letras iguais, nas colunas, não diferem entre si pelo teste de Newman-Keuls, a $5 \%$ de probabilidade $(\mathrm{n}=5)$.

o nível mais elevado de atividade de $\beta$-1,3-glucanases, no tratamento $+\mathrm{Gi}+\mathrm{Fo}$, pode resultar da ativação de resposta de defesa vegetal pela simbiose mutualística, por meio da expressão de isoformas da enzima que atenuaram a severidade de ataque pelo patógeno. A elevação nos níveis pós-infeccionais de quitinases e $\beta$-1,3-glucanases foi constatado somente no tratamento $+\mathrm{Gi}+\mathrm{Fo}$ e, da mesma forma que o observado no portaenxerto resistente, do primeiro experimento, a atividade conjunta dessas enzimas hidrolíticas tem efeito sinérgico que acarreta aumento na capacidade da planta se defender do patógeno radicular.

O decréscimo na biomassa vegetal, causado por Fusarium spp. nas plantas micorrizadas, foi de 37\%, resultado acima do constatado por Al-Askar \& Rashad (2010) em feijoeiros com inoculação de fungos micorrízicos e F. solani f. sp. phaseoli. A micorrização das videiras e a produção de quitinases e $\beta$-1,3-glucanases não tornaram as plantas imunes ao Fusarium spp. A exposição dos tecidos internos e o aumento dos pontos infectivos pela poda facilitaram a invasão pelo patógeno. Em geral, patógenos são inoculados nas plantas pela adição de suspensão de estruturas reprodutivas ao substrato de crescimento das plantas, próximo ao sistema radicular, sem retirada e corte de tecidos (Pozo et al., 1999, 2002; Akköprü \& Demir, 2005). A poda das raízes pode ser condição drástica e propensa à colonização patogênica, embora tenha sido o método mais eficiente na avaliação rápida da resistência de genótipos de videira ao patógeno (Grigoletti Junior, 1985). Em termos práticos, a inoculação de fungos micorrízicos arbusculares não deve constituir estratégia isolada, para se tentar conter $\mathrm{o}$ ataque e infecção por F. oxysporum f. sp. herbemontis. Ao contrario, deve fazer parte de um conjunto de medidas que levem em conta aspectos de manejo do solo como, por exemplo, desenvolvimento de rizosfera supressora de patógenos e não revolvimento do solo, além do uso de recursos genéticos e de nutrição vegetal que favoreçam o desenvolvimento de micorrizas funcionais.

\section{Conclusões}

1. As enzimas quitinases e $\beta-1,3$-glucanases favorecem a supressão de $F$. oxysporum f. sp. herbemontis do sistema radicular do porta-enxerto de videira R110.

2. Glomus intraradices promove aumento na expressão das enzimas hidrolíticas quitinases e $\beta$-1,3-glucanases, no sistema radicular do portaenxerto de videira $\mathrm{SO} 4$, após a inoculação de F. oxysporum f. sp. herbemontis.

\section{Referências}

AKKÖPRÜ , A.; DEMIR, S. Biological control of fusarium wilt in tomato caused by Fusarium oxysporum f. sp. lycopersici by AMF Glomus intraradices and some rhizobacteria. Journal of Phytopathology, v.153, p.544-550, 2005.

AL-ASKAR, A.A.; RASHAD, Y.M. Arbuscular mycorrhizal fungi: a biocontrol agent against common bean Fusarium root rot disease. Plant Pathology Journal, v.9, p.31-38, 2010.

AZCÓN-AGUILAR, C.; JAIZME-VEGA, M.C.; CALVET, C. The contribution of arbuscular mycorrhizal fungi to the control of soil-borne plant pathogens. In: GIANINAZZI, S.; SCHÜEPP, H.; BAREA, J.M.; HASELWANDLER, K. (Ed.). Mycorrhizal technology in agriculture: from genes to bioproducts. Basel: Birkhäuser, 2002. p.187-197.

BORGES, A.J. da S.; TRINDADE, A.V.; MATOS, A.P. de; PEIXOTO, M. de F. da S. Redução do mal-do-panamá em bananeira-maçã por inoculação de fungo micorrízico arbuscular. Pesquisa Agropecuária Brasileira, v.42, p.35-41, 2007. 
CACHINERO, J.M.; HERVAS, A.; JIMENEZ-DIAZ, R.M.; TENA, M. Plant defence reactions against fusarium wilt in chickpea induced by incompatible race 0 of Fusarium oxysporum f. sp. ciceris and nonhost isolates of F. oxysporum. Plant Pathology, v.51, p.765-776, 2002.

CORDIER, C.; POZO, M.J.; BAREA, J.M.; GIANINAZZI, S.; GIANINAZZI-PEARSON, V. Cell defense responses associated with localized and systemic resistance to Phytophthora parasitica induced in tomato by an arbuscular mycorrhizal fungus. Molecular Plant-Microbe Interactions, v.11, p.1017-1028, 1998.

DEYTIEUX, C.; GENY, L.; LAPAILLERIE, D.; CLAVEROL, S.; BONNEU, M.; DONÈCHE, B. Proteome analysis of grape skins during ripening. Journal of Experimental Botany, v.58, p.1851-1862, 2007.

GARCÍA-GARRIDO, J.M.; OCAMPO, J.A. Regulation of the plant defence response in arbuscular mycorrhizal symbiosis. Journal of Experimental Botany, v.53, p.1377-1386, 2002.

GARMENDIA, I.; AGUIRREOLEA, J.; GOICOECHEA, N. Defencerelated enzymes in pepper roots during interactions with arbuscular mycorrhizal fungi and/or Verticillium dahliae. BioControl, v.51, p.293310, 2006.

GARRIDO, L.R.; SÔNEGO, O.R.; GOMES, V.N. Fungos associados com o declínio e morte de videiras no Estado do Rio Grande do Sul. Fitopatologia Brasileira, v.29, p.322-324, 2004.

GRIGOLETTI JUNIOR, A. Fusariose da videira, caracterização, variabilidade do Fusarium oxysporum f. sp. herbemontis e fontes de resistência em Vitis spp. 1985. 76p. Tese (Doutorado) - Universidade Federal de Viçosa, Viçosa.

KOSKE, R.E.; GEMMA, J.N. A modified procedure for staining roots to detect VA mycorrhizas. Mycological Research, v.92, p.486-505, 1989.

KRUGER, N.J. The Bradford method for protein quantitation. In: WALKER, J.M. (Ed.). The protein protocols handbook. $2^{\text {nd }} \mathrm{ed}$. Totowa: Humana Press, 2002. p.15-22.

LEBEDA, A.; LUHOVÁ, L.; SEDLÁROVÁ, M.; JANCOVÁ, D. The role of enzymes in plant-fungal pathogens interactions: review. Journal of Plant Diseases and Protection, v.108, p.89-111, 2001.

NÓBREGA, F.M.; SANTOS, I.S.; CUNHA, M. da; CARVALHO A.O.; GOMES, V.M. Antimicrobial proteins from cowpea root exudates: inhibitory activity against Fusarium oxysporum and purification of a chitinase-like protein. Plant and Soil, v.272, p.223-232, 2005.

POZO, M.J.; AZCÓN-AGUILAR, C. Unraveling mycorrhiza-induced resistance. Current Opinion in Plant Biology, v.10, p.393-398, 2007.

POZO, M.J.; AZCÓN-AGUILAR, C.; DUMAS-GAUDOT, E.; BAREA, J.M. $\beta$-1,3-glucanase activities in tomato roots inoculated with arbuscular mycorrhizal fungi and/or Phytophthora parasitica and their possible involvement in bioprotection. Plant Science, v.141, p.149-157, 1999.

POZO, M.J.; CORDIER, C.; DUMAS-GAUDOT, E.; GIANINAZZI, S.; BAREA, J.M.; AZCÓN-AGUILAR, C. Localized versus systemic effect of arbuscular mycorrhizal fungi on defense responses to
Phytophthora infection in tomato plants. Journal of Experimental Botany, v.53, p.525-534, 2002.

RAMAMOORTHY, V.; RAGUCHANDER, T.; SAMIYAPPAN, R. Induction of defense-related proteins in tomato roots treated with Pseudomonas fluorescens $\mathrm{Pfl}$ and Fusarium oxysporum f. sp. lycopersici. Plant and Soil, v.239, p.55-68, 2002.

SALZER, P.; BONANOMI, A.; BEYER, K.; VÖGELI-LANGE, R.; AESCHBACHER, R.A.; LANGE, J.; WIEMKEN, A.; KIM, D.; COOK, D.R.; BOLLER, T. Differential expression of eight chitinase genes in Medicago truncatula roots during mycorrhiza formation, nodulation, and pathogen infection. Molecular Plant-Microbe Interactions, v.13, p.763-777, 2000.

SCHAEFER, H. Über Extraktion von Proteinen und Enzymen aus verholzten Rebenorganen. I. Extraktion für die elektrophoretische Auftrennung. Wein-Wiss, v.32, p.269-288, 1977.

SCHOFFELMEER, E.A.M.; KLIS, F.M.; SIETSMA, J.H.; CORNELISSEN, B.J.C. The cell wall of Fusarium oxysporum. Fungal Genetics and Biology, v.27, p.275-282, 1999.

SCHUCK, E.; DAL BÓ, M.A.; ANDRADE, E.R. de.; ROSIER, J.P. Uva. In: EPAGRI. Avaliação de cultivares para o Estado de Santa Catarina 2007/2008. Florianópolis: Epagri, 2007. p.139-143.

SMITH, G.S.; JOHNSTON, C.M.; CORNFORTH, I.S. Comparison of nutrient solutions for growth of plants in sand culture. New Phytologist, v.94, p.537-548, 1983.

TROUVELOT, A.; KOUGH, J.L.; GIANINAZZI-PEARSON, V. Mesure du taux de mycorhization VA d'un système radiculaire. Recherche de méthodes d'estimation ayant une signification fonctionnelle. In: GIANINAZZI-PEARSON, V.; GIANINAZZI, S. (Ed.). Mycorrhizae: physiology and genetics. Dijon: Institut National de la Recherche Agronomique, 1986. p.217-221.

TUZUN, S. The relationship between pathogen-induced systemic resistance (ISR) and multigenic (horizontal) resistance in plants. European Journal of Plant Pathology, v.107, p.85-93, 2001.

VERONESE, P.; RUIZ, M.T.; COCA, M.A.; HERNANDEZ-LOPEZ, A.; LEE, H.; IBEAS, J.I.; DAMSZ, B.; PARDO, J.M.; HASEGAWA, P.M.; BRESSAN, R.A.; NARASIMHAN, M.L. In defense against pathogens: both plant sentinels and foot soldiers need to know the enemy. Plant Physiology, v.131, p.1580-1590, 2003.

WIRTH, S.J.; WOLF, G.A. Micro-plate colourimetric assay for endoacting cellulase, xylanase, chitinase, 1,3- $\beta$-glucanase and amylase extracted from forest soil horizons. Soil Biology and Biochemistry, v.24, p.511-519, 1992.

ZEMKE, J.M.; PEREIRA, P.; LOVATO, P.E.; SILVA, A.L. da. Avaliação de substratos para inoculação micorrízica e aclimatização de dois portaenxertos de videira micropropagados. Pesquisa Agropecuária Brasileira, v.38, p.1309-1315, 2003.

ZHU, H.H.; YAO, Q. Localized and systemic increase of phenols in tomato roots induced by Glomus versiforme inhibits Ralstonia solanacearum. Journal of Phytopathology, v.152, p.537-542, 2004.

Recebido em 8 de fevereiro de 2010 e aprovado em 11 de março de 2010 